\title{
Disaster mitigation of climate change effects on small islands (case of Harapan and Kelapa Islands)
}

\author{
Ade Panca Zulriskan ${ }^{1}$, Raldi Hendrotoro Koestoer ${ }^{2, *}$, and Adil Faisal Alwini ${ }^{3}$ \\ ${ }^{1}$ Graduate Student Magister Program of School of Environmental Science, University of Indonesia, \\ Salemba 4 Jakarta. \\ ${ }^{2}$ School of Environmental Science, University of Indonesia, Salemba 4 Jakarta. \\ ${ }^{3}$ Student Magister Program of School of Environmental Science, University of Indonesia, Salemba 4 \\ Jakarta.
}

\begin{abstract}
The vulnerability is the sequence of condition that determines whether a hazard will cause disaster or not. The small islands are easily affected by the climate change effects. The small islands are particularly vulnerable to the projected of climate change effects. Harapan and Kelapa Islands is a small island in the Thousand Islands Region, DKI Jakarta Province. This study aims to analyze of climate change effects on social, economic, and environmental on small islands. This study using key indicators consist of social, economic, environment, and climate change. The methods applied in this research is GIS and system dynamics or called by spatial dynamics. The result showed that the area of study categorized as the vulnerable area to the climate change effects, this is due to the increasing sea level rise and rainfall, the growing population number and density, and the expanding built area. Therefore, the need for disaster mitigation and adaptation efforts on the climate change effects.
\end{abstract}

\section{Introduction}

Disaster mitigation of climate change effects is one of the ways that small islands can be sustainable. The Sustainable Development Goals implicitly require life cycle thinking as a step to prioritize action by determining the key drivers of social and environmental problems, and to ensure that no unintended trade-offs occur.

Coastal areas and small islands are rich in diversity of natural resources, such as fisheries, mangrove forests, coral reefs, petroleum, mining materials, and gases and minerals [1]. In addition to having large numbers, small islands are generally limited to terrestrial natural resources but have enormous marine resources.

Small Island has a characteristic effect due to the small size of the land as well as isolated (insular) of the big island (mainland) [6].

\footnotetext{
* Corresponding author: ralkoest@yahoo.co.uk
} 
There are four typical constraints of small islands to be considered in the economic assessment of small island resources, ie smallness, isolation, dependence and vulnerability [2]. However, small islands if well managed can also sustainable.

One example of small islands group that have the potential of natural resources and high economic value as mentioned above is Harapan and Kelapa Islands. Administratively this cluster of small islands entered into the District Administration Area of Thousand Islands, Province Special Capital Region (DKI) Jakarta. Harapan Island and Kelapa Island are located in North Kepulauan Seribu District. Uniquely, from the clusters of these small islands, the two islands have different administrative areas, although the location is adjacent between islands and bridges built as access between the two islands. Both islands are populated island, Harapan Island area of $12.35 \mathrm{Ha}$ and the population in 2017 as many as 1824 people. The area of Kelapa Island is $26.58 \mathrm{Ha}$ with population 6,240 people in 2017 [7].

The territory of small islands is weak and vulnerable region affected by climate change. The issue of climate change is the most complex multidimensional challenge facing mankind over the past decade. Global climate change has been proved by scientific facts that are with the increase in average temperature of the earth's surface. Inter-governmental Panel on Climate Change (IPCC) in 2007 [4] has stated that climate change activity has affected the continuity of atmospheric dynamics across the world. Predicted by the IPCC in 2007, showed that average sea level rise of $2.5 \mathrm{~mm} /$ year and estimated to be $31 \mathrm{~mm}$ in the next decade. A number of researches that have been conducted in several countries around the world have indicated a shift from extreme weather behaviour with respect to climate change action. Global climate change increases extreme events, such as extreme rainfall, extreme temperatures, and storm intensity [3].

In anticipating the impacts of climate change, disaster mitigation of small islands is required. It aims to the citizen of small island can adapt to their vulnerable areas which is has the high risk effect of climate change. Some of disasters caused by climate change are sea level rise (sea level rise), tornado, extreme waves, and others.

\section{Data and method}

The approach used in this research is quantitative approach with spatial dynamics modelling method. The consideration of using a quantitative approach based on the objective of this research is to build a sustainable small island archipelago model by looking at the impacts of climate change so that future land use predictions are obtained. The research was conducted in the Thousand Islands District Administration area which includes Harapan Island and Kelapa Island (can be seen in Figure 1). The scope of research on both islands includes landuse and climate change impacts on both islands.

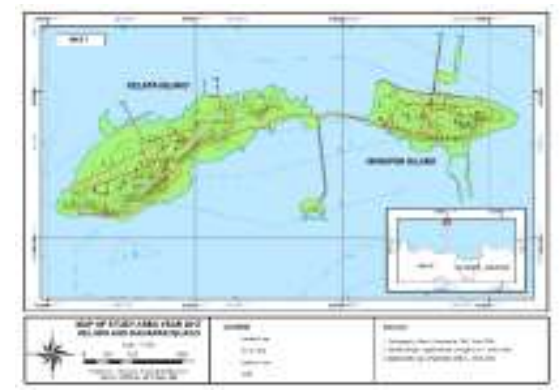

Fig. 1. Map of study area. 
Data collection in this study included field survey and literature study. The method of analysis in this research consists of analysis of landuse change and spatial dynamics modelling analysis.

Spatial dynamics modelling method using land attractiveness approach. The attractiveness of the land is derived from the benefits and cost of the driving force multiplied by the weight of the landuse [5]. The weights were calculated from the analysis using the conformity test model by costanza. This model is to measure the similarity of patterns between driving forces and land expansion.

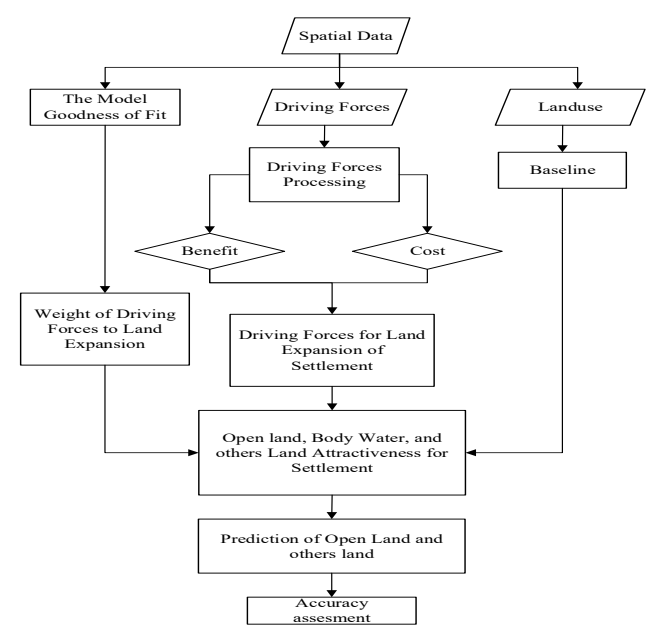

Fig. 2. Flowchart of spatial modelling.

\section{Result and Discussion}

\subsection{Physical Characteristics of Territories}

Based on the results of NOAA image interpretation in 2017, the area of study in 2017 is $38.93 \mathrm{Ha}$, with details of Kelapa Island covering $26.58 \mathrm{Ha}$ (10\% of Kelapa Island area) and Harapan Island area of $12.35 \mathrm{Ha}$ (5\% wide Harapan Island Village). The area of study within 10 years is always increasing, this can be seen in Table 1, the area increased in both islands with details of Island of Harapan in the period of 10 years increased by $1.52 \mathrm{Ha}$, while for Kelapa Island within 10 years increased by 2.41 Ha. Based on field observations, the extent of the study area is influenced by the reclamation.

Table 1. Wide Area of Study 2007-2017 Years.

\begin{tabular}{|l|l|l|l|l|}
\hline \multicolumn{1}{|c|}{ Village } & \multicolumn{1}{|c|}{ Island } & $\begin{array}{c}\text { Wide of 2007 } \\
\text { Year (Ha) }\end{array}$ & $\begin{array}{c}\text { Wide of 2012 } \\
\text { Year (Ha) }\end{array}$ & $\begin{array}{c}\text { Wide of 2017 } \\
\text { Year (Ha) }\end{array}$ \\
\hline Pulau Kelapa & Kelapa & 24.15 & 25.84 & 26.58 \\
\hline Pulau Harapan & Harapan & 10.83 & 11.36 & 12.35 \\
\hline
\end{tabular}

Souce : Interpretation Landsaat Image 2007-2017 years

The people of Kelapa and Harapan Islands mostly work as fishermen according to the condition of the study area which is surrounded by the sea. Many communities are turning professions from fishermen into servants of services. In addition, based on interviews with 
the community and political district administrated employees in the study area, stated that many people who used to work as fishermen are now turning professions into tour guides, as well as many who turn professions into cultivated fishermen. One of the factors influencing the change of profession in the community of these two islands is the difficulty of catching fish in nearby waters near these two islands as climate change impact.

\subsection{Landuse 2017}

The landuse in 2017 in Kelapa Island based on Table 2 is dominated by settlements with an area of 18.20 Ha. Further Green Open Space (RTH) dominates with an area of 5.19 Ha and open land with an area of $1.53 \mathrm{Ha}$. Kelapa Island has no graves and garbage dumps (TPS). The land use of 2017 on Harapan Island based on Table 2 is dominated by settlements with an area of $7.84 \mathrm{Ha}$. Furthermore, open land dominates with an area of $1.59 \mathrm{Ha}$ and a grave with an area of 1 ha.

Table 2. Land use 2017 Year.

\begin{tabular}{|c|c|c|}
\hline Landuse & Kelapa Island (Ha) & Harapan Island (Ha) \\
\hline Body Water & 0.21 & 0.16 \\
\hline Built Area & 0.48 & 0.3 \\
\hline Jetty & 0.3 & 0.1 \\
\hline Bridge & 0.28 & 0.19 \\
\hline Open Land & 1.53 & 1.59 \\
\hline Cemetery & 0 & 1 \\
\hline Settlement & 18.2 & 7.84 \\
\hline Park & 0.4 & 0.12 \\
\hline Green Space Area & 5.19 & 0.89 \\
\hline Garbage Area & 0 & 0.15 \\
\hline Total & 26.58 & 12.35 \\
\hline
\end{tabular}

The land use map of Kelapa Island and Harapan Island in 2017 explains that almost all areas of study are dominated by settlements. In 2017 settlements increased compared to 2007 and 2012, the addition of residential areas in the study area, one of which is caused by the increasing population growth from year to year, so the need for settlement land is increasing as well.

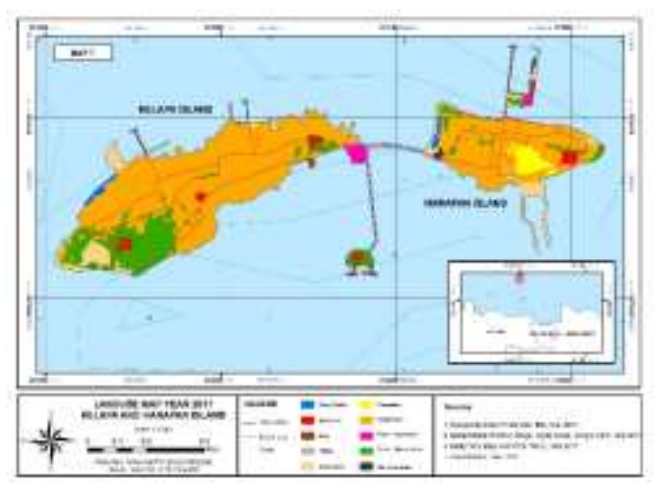

Fig. 3. Land use 2017. 


\subsection{Analysis of the Impacts of Climate Change on Socio-Economic Conditions}

The damage caused by the impact of climate change resulted in the disruption of the activity of the small island communities who depend their lives on coastal natural resources around the island. The impacts of climate change directly affect the condition of fishermen and settlements in the study area. People in the livelihoods study area as fishermen are highly exposed to the phenomenon of climate change impacts. However, the perception of fishermen related to climate change is not really aware of the phenomenon of climate change. They only understand, that now looking for fish has been difficult for a short distance to where they live. From field interviews many fishermen have side jobs as tour guide or homestay guard, this is one of them due to the impact of climate change which resulted in the difficulty of finding fish, sea salinity increased, affecting fishery commodities, it is difficult to determine the fishing season due to damage to coral reef ecosystem, and the risk of going to sea due to extreme weather.

The changes felt by fishermen in the study area have some social implications on the fisherman's livelihood system. In the study area, some fishermen also perceive some coastal and marine ecological changes based on their daily experiences that can be associated with the phenomenon of climate change. The fishing communities in the study area felt ecological changes including sea level rise, storm and high intensity, fishing ground changes and seasonal chaos. Fishermen feel that strong winds accompanied by tidal waves in recent years are more common. In 2015, a whirlwind caused the destruction of several houses in the study area. Therefore, an understanding of mitigation and adaptation for the community in the study area needs to be provided by the Regional Government, so that emergency response can be undertaken by the community in the study area.

\subsection{Model of Land Use Against Climate Change Impact}

This model, done with two scenarios. The first scenario is the model built on the assumption that settlements only grow in the type of land use of open land and coastal seawater, this is due to actual conditions that occur in the study area. The second scenario is the model is built on the assumption that the area of study can not increase, due to sea level rise, frequent occurrence of extreme waves, and the increasing intrusion of sea water, so that settlements will only switch function in the type of land use and some areas of green space which can be converted into several residential areas due to increased population growth.

The area of settlements in the study area in 2017 amounted to $26.04 \mathrm{Ha}$, then with the model simulation results are executed then in 2032 the settlement area to $29.95 \mathrm{Ha}$. It can be concluded that with the first scenario, model simulation results are executed, the area of study in 2032 increased to $42.84 \mathrm{Ha}$, this is because there is an increase in the area of settlements about 3.91 Ha. These settlement areas are increasingly around the coasts of the two islands and are located in the northern and southern regions of the two islands. Furthermore, in the first scenario, the variable impact of climate change is not used, because the existing conditions in the study area, the area of land every year is always increasing, then the public understanding of the phenomenon of climate change is not comprehensively comprehended by the community in the study area. This can be seen in Figure 4. 


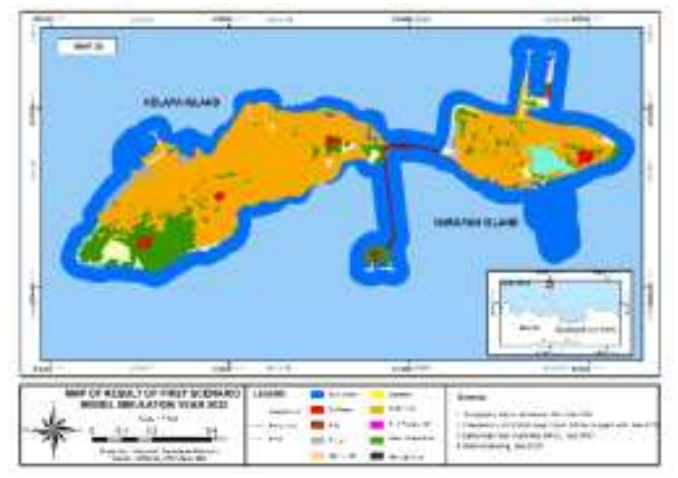

Fig. 4. Results of First Scenario Model Simulation Year 2032.

The simulation result of the second scenario model, model run from 2012 -2032, assuming $1 \%$ a year of settlement growth, the simulation result that the settlement area increase from the conversion of land use type of open land, water body and RPTRA, in the study area increased to $4.01 \mathrm{Ha}$. The area of settlements in the study area in 2017 amounted to 26.04 hectares, then in 2032 the settlement area to 30.05 Ha. However, the area is not increased or can be said to remain $(38.93 \mathrm{Ha})$. This can be seen in Figure 5.

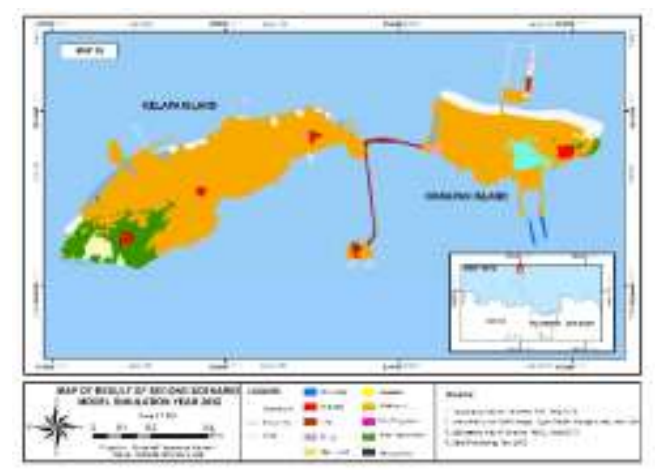

Fig. 5. Results of Second Scenario Model Simulation Year 2032.

In this second scenario, the variables of climate change impacts are used as an intervention in running the model. In addition, the growth of settlements along the coast in both islands can be stopped, because if settlements are always built around the coast, then the incidence of abrasion disaster will be easy to happen. Furthermore, in the coastal areas near the coastal need for the addition of mangrove ecosystems and seagrass beds. In addition, the construction of coastal embankments and breakwaters to be one of the efforts in anticipation of rising sea levels increased seawater intrusion, and increased intensity of extreme waves.

Besides, by including variables of climate change impact, the condition of the study area is not changed, because if every year the area of study always increase its extent, the incident of intrusion of seawater to the land becomes easy to happen. Therefore, the strategy or effort that must be done by the Provincial Government and Local Government is to prohibit the community especially those living around the coast of Harapan Island and Kelapa Island. Then, if the community commits a violation of additional land area will be sanctioned. 


\section{Conclusion}

Changes in land use in the study area, within 10 years of area in the study area always experienced growth of $3.9 \mathrm{Ha}$. The impact of climate change on socio-economic conditions has a direct impact on the income of the people, especially those living as fishermen. Therefore, in the study area many fishery fishermen catch livelihoods to be cultivated fishermen and tour guide. Model simulation results show that the second scenario with climate change impact interventions is more likely to be used for future spatial-based mitigation and disaster adaptation arrangements.

\section{Acknowledgements}

This research is funded by the Grant of Indexed International Publication for Final Project of Students Publikasi Terindeks Internasional untuk Tugas Akhir Mahasiswa (PITTA) Universitas Indonesia 2018.

\section{References}

1. R. Dahuri, J. Rais, S.P. Ginting, M.J. Sitepu, Integrated Coastal and Marine Resource Management (2001)

2. A. Fauzi, Economic Valuation of Small Island Resources (2002)

3. P. Frich, L.V. Alexander, P. Della-Marta, B. Gleason, M. Haylock, A.M. Tank, T. Peterson, Climate Research 19, 3 (2002)

4. [IPCC] Intergovernmental Panel on Climate Change. (2007). Climate Change: The Physical Science Basis. Summary for Policy Makers, Contribution of Working Group I to the Fourth Assessment Report of the Intergovernmental Panel on Climate Change. Paris, February (2007)

5. D. Priyanto, Spatial Modeling On Land Attractiveness For Sustainable Development In Surabaya (2017)

6. B.S. Susilo, Sustainability Development of Small Islands Case Study of Panggang Island and Pari Island Villages, Thousand Islands, DKI Jakarta (2003)

7. Statiscal Data Harapan and Kelapa Village (2017) 